\title{
Krause on Animal Rights and Ecological Sustainability
}

\author{
Claus Dierksmeier
}

\section{Introduction}

In contrast to the neglect the philosophy of Karl Christian Friedrich Krause (17811832 ) is met with in the Anglophone world, ${ }^{1}$ to date many Spanish, Portuguese, and Latin-American philosophers esteem Krause as the progenitor of a socially progressive philosophy of freedom with cosmopolitan aspirations. ${ }^{2}$ Krause's iberophone followers are onto something. On close inspection, Krause does indeed appear to offer something of particular value for contemporary philosophy. Expanding the Kantian project of a self-critical philosophy of freedom, Krause arrived at an inclusive liberalism, which, directed to any and all persons, already considers - at the outset of the $19^{\text {th }}$ century issues such as the legal representation of unborn children, minors, the disabled, disenfranchised peoples, and future generations. Moreover, Krause argued also for applying the concept of personhood and certain concomitant rights to animals. Last, not least, concerning plants and inorganic matter, Krause advocated for policies of ecological sustainability that were to safeguard an intact environment not only for present but also for future generations. Reason enough, or so I will argue, to revisit Krause's freedombased ethics and see which potential it holds for current debates on animal rights and ecological sustainability.

In what follows, I first give a brief sketch of the reception of Krause's philosophy and situate it within the philosophical context of 1800 , with a particular focus on his critique of Fichte's deduction of rights. Krause rejected Fichte's insistence upon relations of symmetrical reciprocity for the ascription of - always mutually conditioned - rights. He fended instead for a conception of unconditionally grounded rights which were to be granted, preserved, and protected also within asymmetrical relations (II.). This move allowed Krause to extend legal entitlements to subjects who (like members of future generations or animals) are not in a position to reciprocate in kind. This extension of rights to subjects outside of traditional national polities or social contracts depends on how Krause's ethics was erected on the premises of a nuanced, non-speciesist philosophy of freedom, as will be reconstructed thereafter (III.). Next, I introduce his reflections on animal rights (IV.) and how these can and must be distinguished from the rights of all members, even of severely incapacitated or disabled members, of the human species. Subsequently, I portray (V.) why, according to Krause, even plants and inorganic

\footnotetext{
${ }^{1}$ Apart from occasional references to Krause by Thomas Hill Green and James Lorimer, in the Anglophone world, only Clay MacCauley displays genuine enthusiasm for Krause. See his, Krause's 1818 League of Peace, The Advocate of Peace 81:2 (1919), 43 ff.; and Krause's League for Human Right and Thereby World Peace, Tokyo, 1917.

${ }^{2}$ See Dierksmeier, Krausism, in: Nuccetelli/Schutte/Bueno (eds.), A Companion to Latin American Philosophy, 2010, 110-123.
} 
nature should be treated in a sustainable manner, before concluding (VI.) with some reflections on the past reception and potential future role of Krause's philosophy.

\section{Reception, Context, and Krause's Critique of Fichte}

Although Krause's philosophy was largely forgotten in his homeland, Germany, for a long time, since the 1980s it is again receiving attention; and that is as it should be, since it played a key role in the history of ideas, insofar as Krause pioneered ideas which were later of formative importance for German Idealism as a whole. ${ }^{3}$ Moreover, slowly but surely not only the historic but also the systematic contributions of Krause are being acknowledged. This renewed appreciation has much to do with the reception Krause's philosophy found in many Spanish speaking countries, where his thoughts inspired the political movement of krausismo, a socially progressive and environmentally sensitive liberal cosmopolitanism. ${ }^{4}$

For over half a century, from the middle of the 1860s until its suppression by Franco in the middle of the $1930 \mathrm{~s}$, krausismo shaped the constitutional life and political culture of Spain. ${ }^{5}$ The same is true of Argentina and Uruguay, where, since the 1870s, whole generations of presidents were committed to the Krausist thinking - until, in the second half of the twentieth century, dictators took over power and suppressed all liberal ideologies. Immediately after the end of those dictatorships, the first democratically elected presidents of those countries (and the parties supporting them) again avowed Krause's intellectual heritage. This applies both to the Argentinian President, Raúl Alfonsín, and Argentina's liberal party, Unión Cívica Radical (UCR), which was very popular during his time in office, as well as to the Battle family in Uruguay, which since produced several heads of state. ${ }^{6}$

Up until the 1990s, it was believed that the programmatic publications of krausismo were original creations of Iberian culture. Enrique Ureña's textual analyses have shown, however, that the writings that Julian Sanz del Río (the father of Spanish krausismo) distributed to his people were - contrary to what he made his readers believe - nothing but cleverly arranged translations of Krause's original texts. ${ }^{7}$ A few years ago, Ureña also presented extensive and meticulously researched studies which set the record straight with regard to Krause's impact on his homeland. Ureña could show that there indeed was, in a manner of speaking, something like a "German Krausism" at the end of the nineteenth century. ${ }^{8}$

${ }^{3}$ See the comprehensive studies by Ureña, K. C. F. Krause: Philosoph, Freimaurer, Weltbürger: Eine Biographie, 1991, and, Philosophie und gesellschaftliche Praxis: Wirkungen der Philosophie K. C. F. Krauses in Deutschland (1833--1881), 2001, as well as Dierksmeier, Der absolute Grund des Rechts: Karl Christian Friedrich Krause in Auseinandersetzung mit Fichte und Schelling, 2003.

${ }^{4}$ See Gil-Cremades, Die politische Dimension des Krausismo in Spanien, in: Kodalle (ed.), Karl Christian Friedrich Krause (1781-1832): Studien zu seiner Philosophie und zum Krausismo, 1985, 221-223.

${ }^{5}$ See Hennessy, The Federal Republic in Spain: Pi y Margall and the Federal Republican Movement, 1868-1874, 1962 and Trend, The Origins of Modern Spain, 1934, 30-49.

${ }^{6}$ See Ureña, Krause hoy, in: Casella (ed.), Las ideas filosóficas que influyeron en la formación del Uruguay contemporáneo, 1988, 19-27.

${ }^{7}$ See Ureña, K. C. F. Krause: Philosoph, Freimaurer, Weltbürger, 1991.

${ }^{8}$ See Ureña, Philosophie und gesellschaftliche Praxis, 2001. 
But let us begin at the beginning: In early nineteenth-century philosophy, numerous thinkers strove to apply Kant's theory of freedom to various ethical questions. In the competition to be Kant's official successor, Fichte first took the lead, by surpassing many of his competitors by virtue of the systematic rigor of his approach. Krause, although he was deemed to be Fichte's best student, ${ }^{9}$ nevertheless rejected this view. At the age of 22, he published a legal philosophy, which, in its structure and content, as well as its title, competed with Fichte's Foundations of Natural Right. In his own Foundations of Natural Right from 1803, Krause explicitly accused Fichte's philosophy of grave structural and theoretical deficiencies. ${ }^{10}$

Against Fichte, Krause defends the everyday consciousness of people - and its typical assumption of an independent external world (K 5). ${ }^{11}$ Krause does not identify a world to which one - among other things - relates oneself morally with a world that actually exists solely for that purpose; a world, that is to say, which, abstracted from the moral objectives of human freedom, possesses no intrinsic value. To follow Fichte's views - Krause held - invites an unfortunate dualism between the reasonable (the realm of moral freedom) and the unreasonable (the realm of amoral necessity) and, by extension, an undue opposition between humanity (incorporating and representing the principle of freedom) and nature (as supposedly determined by sheer necessity). These dichotomies must be overcome.

Fichte's conception, Krause avers, cannot productively synthesize the 'I' with nature, so that freedom inevitably comes into opposition with nature, and one ends up with "precisely that erroneous view of nature as inhibition and obstruction, but not real life" (K 5), for which Krause criticizes Fichte. In such a theory, free activity in nature must degenerate into the demand for a radical actualization of freedom against everything that is not yet reasonable - and thus also against nature. According to Krause, this is the origin of Fichte's philosophical transformation of nature into nothing but a dead "material of duty" (GA 1/5, 353; AD 25) as well as of Fichte's advocacy of the devaluation of animals and plants as in themselves worthless things, which is strongly criticized by Krause (GW 455).

\footnotetext{
${ }^{9}$ See Orden Jiménez, El Sistema de la filosofia de Krause: Génesis y desarrollo del panenteísmo, 1998, 41-56.

${ }^{10}$ For the textual history and intellectual background of this work, see Forster, Karl Christian Friedrich Krauses frühe Rechtsphilosophie und ihr geistesgeschichtlicher Hintergrund, 2000.

${ }^{11}$ Krause's writings are referenced (in my translation) by means of the following abbreviations: (AR): Abriss des Systemes der Philosophie des Rechtes oder des Naturrechts (1828); (ERB): Der Erdrechtsbund an sich selbst und in seinem Verhältnisse zum Ganzen und zu allen Einzeltheilen des Menschheitlebens, Georg Mollat, ed. (1893); (G): Grundlage des Naturrechts, oder philosophischer Grundriss des Ideales des Rechts. Erste Abteilung (1803); (G II) Grundlage des Naturrechts oder philosophischer Grundriss des Ideales des Rechts. Zweite Abtheilung, Georg Mollat, ed. (1890); (GW): Vorlesungen über Grundwahrheiten der Wissenschaft, zugleich in ihrer Beziehung zu dem Leben. Nebst einer kurzen Darstellung und Würdigung der bisherigen Systeme der Philosophie, vornehmlich der neuesten von Kant, Fichte, Schelling und Hegel, und der Lehre Jacobi 's. Für Gebildete aus allen Ständen (1828); (K): Erklärende Bemerkungen und Erläuterungen [Kommentar] zu J. G. Fichtes Grundlage des Naturrechts, Georg Mollat, ed. (1893); (LL): Lebenlehre oder Philosophie der Geschichte zur Begründung der Lebenkunstwissenschaft (1904); (Nph): Anleitung zur Naturphilosophie. I. Deduction der Natur, II. Anleitung zur Construction der Natur (1804); (NR): Vorlesungen über Naturrecht oder Philosophie des Rechts und des Staates, R. Mucke, ed. (1892); (VR): Das System der Rechtsphilosophie - Vorlesungen für Gebildete aus allen Ständen, K. A. D. Röder, ed. (1874).
} 
Krause raises similar objections against Fichte's theory of intersubjectivity, ${ }^{12}$ in which the early Fichte had advocated that, in order not to forfeit one's claim to recognition, people have to demonstrate their status - and dignity - as reasonable and free beings through thoroughly ethical conduct. According to Krause, however, dignity is something that can neither be won nor lost (K 11). Hence, the forever conditioned reciprocity of factual recognition cannot justify the basic right of all human beings to be recognized as moral and reasonable. Rather, the unconditioned right to be respected in one's dignity justifies an absolute legal obligation (Rechtspflicht) towards general recognition. In direct opposition to Fichte, Krause therefore demands: "Treat as a reasonable being also one who treats you as an unreasonable being, who does not respect your reasonableness" (K 13 f.; italics in the original). Even "if no one respected me, this would not mean that I am no longer duty-bound towards respect in general, not even legally" (ibid.).

As a consequence, Krause rejects Fichte's doctrine that the foundation of law is the symmetry and reciprocity of legal commitments in favor of a rehabilitation of "original rights" (Urrechte) of personality (K 29). In short, the freedoms owed to every human being do not result from reciprocal exchange or contract. One is not only (hypothetically) obligated to enable the freedom of all persons if and insofar as one can expect symmetrical commitments in return. There is rather a (categorical) duty to enable everyone's freedom, and this duty also extends to thoroughly asymmetrical relations such as, for example, the rights of future generations or of people with disabilities, or, as we will show below, also of animals (K 37).

In the same vein, Krause attacks Fichte's theory that people's wrongful actions could extinguish the constitutive legal relationship between us and others (K38). Nothing can rob persons of their inherent right to be treated according to their status as free entities (VR 116). Succinctly and powerfully, Krause notes:

\footnotetext{
"The thesis is false, for its condition [i.e., that the other acts illicitly] is in no way the foundation of legal status, but this is rather the reasonable nature [i.e., of the other]. It is impossible that the latter be stripped off by a single illicit action [...]. Therefore, Fichte's positing of rigid consequences is unjust" (K 46).
}

For Krause, because of its inherent freedom, human life has an unconditioned dignity which is - even for the respective persons themselves - inviolable. Consequently, he proclaims universal "rights for world citizens" (Weltbürgerrechte), which are to guarantee certain freedoms to all human beings, not based on their specific citizenship or affiliations, but in virtue of their sheer personhood. Concerning those cosmopolitan rights, Krause writes:

\footnotetext{
"They belong to me not insofar as I am a citizen of this particular region and state, but insofar as I am a citizen of the world. I can thus call them, together with the rights to my body, as the proximate condition of their attainment, my rights as a world-citizen, and call my possession of them my cosmopolitan property; they rank higher than any positive form of coercion and are indelibly etched into the legal constitution of the world" (G 28).
}

\footnotetext{
12 These objections do not affect Fichte's later theory of intersubjectivity. Since Krause had intimate knowledge of the Wissenschaftslehre nova methodo (today's text is based upon Krause's lecture notes) - and employed a similar approach within his own theory of intersubjectivity - these later configurations of Fichte's theory were not Krause's target.
} 
But humans are not the only beings on earth characterized by freedom, and thus the question arises, what kind of rights have to be ascribed to the other extant free beings on earth: animals.

\section{The Ethical Criterion: Freedom}

In Krause's philosophy, liberty is never license. His aim is not a quantitative maximum of options for individuals. Rather, Krause charges individual freedom with cosmopolitan responsibility and tries to optimize the freedoms of each with and through the liberties of all. To make freedom the bedrock of ethics is for Krause, consequently, not tantamount to a libertarian voluntarism. Rather than reducing morality to the contingent collusion between contractual parties negotiating their respective liberties, just as if human discretion alone conferred moral value upon the world, Krause argues that the idea of freedom is intrinsically committed to do justice to the world that it shapes: From the indispensability of human freedom for moral values it thus does not follow that freedom alone presents a good to be respected. Rather, freedom fulfills itself in the effort to relate properly to its world and contexts, and so humanity is tasked with grasping the inherent value of the natural environment adequately - a tall order. Krause takes up this challenge to give a fair account of the immanent value of other life-forms by presenting and discussing different levels of freedom and consciousness of freedom-in-nature as the crucial criterion for accepting non-human interests as morally pertinent.

Via a phenomenology of human freedom, he first distinguishes "three essentially different levels of finite reasonable personality" and the grades of freedom belonging to each (VR 245). The lowest form of freedom describes individuals with only a bodily form of self-direction. The next level incorporates persons, who direct their behavior mentally but proceed thereby only (pragmatically) rationally (verständig) and not also (morally) reasonably (vernünftig), i.e., whose acts are only conditionally motivated and not based upon unconditional reasons. The third level of freedom describes those who, in addition, become self-conscious in a reflexively philosophical manner and from this standpoint critically evaluate their preferences. "As to these three levels of reasonableness, we find all three of them presented in certain ways by the human beings upon this earth" (VR 245).

Every human being initially repeats in his personal development "certain periods" of vegetative and animalistic life (LL 18), within which he nevertheless would only remain as a result of a lack of education or disability. For most of their lives, most human beings act according to the second level of consciousness of freedom, i.e., in the mode of self-assertive finality. To a human being in the full sense there potentially belongs, however, also said highest level of consciousness - self-critical freedom - as well as, actually, a more or less conscious striving towards it.

For Krause, even extreme mental and/or physical disability in no way entails a loss of human dignity (VR 247). Human beings "however deformed and deficient, however stunted, however mentally or physically ill, however immersed in misery" they may be, cannot be deprived of the dignity and rights germane to their species-bound personhood (LL 180). Rather, for the sake of their human dignity, society is obligated to ensure the realization of their rights for them and take special care of disabled persons (G II, 189). ${ }^{13}$

\footnotetext{
${ }^{13}$ See Garrido, Francisco Giner de los Ríos. Creador de la Institución Libre de Enseñanza, 2001, 88.
} 
The disabled have an entitlement to expect that others, and in particular the state, will help them make the most dignified use of their remaining scope of freedom (G II 189). And this entitlement to social support is not conditional on returns. It belongs to the dignity of all human beings that their rights be unconditionally granted to them.

\begin{abstract}
"Insofar as the individual citizen is affected by one or more unavoidable limitations in body and soul, he can be incapable of naturally fulfilling some legitimate requirements or become incapable of this within the course of his life. To these belong those who are born without genius, those born blind, those born deaf and dumb, those who are naturally weak, etc., as well as those who are weakened by sickness or mechanical damage to body or spirit, or both. Now because, as is proven, the possession of the rights that are supposed to be awarded to him are in no way originally legally founded upon what he does in return, they are rather established by the constantly available demands of reason, so can the same unfortunate [person] [...] in no respect be or become legally incapacitated as a result of his misfortune" (G II 149).
\end{abstract}

By way of legal representation, society assures that rights can also be enjoyed by individuals who do not (or are unable to) demand them. ${ }^{14}$ For this purpose, Krause promulgates a universal legal guardianship of humanity for all individuals. In contrast to many thinkers before him, Krause does not draw on factual dependency in order to legitimate legal dependency but conversely forges - from the legal equality of all persons - an argument for the quickest possible improvement of degrading forms of life. This legal guardianship, however, should - as much and as soon as possible - render itself superfluous (VR 459). Representation is to be exercised in this emancipatory sense alone. Inasmuch as, for instance, a child can adequately handle its own freedom, it should no longer be kept in tutelage; the same is true, mutatis mutandis, of people with disabilities who always only partially, and never totally, fall under the care of others (VR 458 f.). Liberation towards autonomy is both the legitimation and limitation of all representation (NR 155). Something similar, as we will see below, holds for animal freedom and animal rights.

The various levels of maturity which human freedom moves through involve various forms of responsibility (LL 127ff.). Individual life begins - Krause holds - with "sensory freedom," which takes its cues from context, follows habits, and customs (VR 441). On the next level of "rational freedom [verständiger Freiheit]" individuals set about making themselves more independent of their contexts - specifically through rational abstraction and, for instance, by emphasizing their subjective characteristics in contradistinction to society (ibid.). That intellectual freedom leads to the productive liberation of individual capacities and energies, but - exclusively exerted - also to onesidedness and isolation. It needs to be rectified by a "reasonable freedom" [vernünftige Freiheit] (ibid). This highest level of human freedom refers to the capacity for self-commitment in the name of ethical aims (ibid.). Through this capacity, human beings can enter into higher forms of community that transcend the level of merely interest-bound associations. In other words, whereas the second level of rational freedom brings about only conditional alliances that the vicissitudes of changing interests both make and break at any moment, the third level of reasonable freedom can obligate humans unconditionally to erect and maintain forms of cooperation with lasting as well as overarching moral ambitions. It is the moral obligation of humanity, therefore, to coordinate human

\footnotetext{
${ }^{14}$ See Lorimer, The Institutes of Law: A Treatise on the Principles of Jurisprudence as Determined by Nature, 1872,308 .
} 
life so that persons can develop and articulate their entire range of freedoms with respect to the autonomy of all other free beings.

From these premises, Krause derives postulates for the ethical treatment of animals which contrast sharply with the customary opinions of his time and era. In the philosophy of the late eighteenth and early nineteenth century, nature was often reduced to a mere object of human activity, worthless in and of itself, and valuable only as the wherewithal for human agency. Thus, if animals were considered worthy of legal protection, then typically as objects, rarely as subjects, of the law. That is to say, when philosophers did not dismiss the idea of legal protection of animal welfare out of hand, they typically adduced anthropocentric reasons why it might be in the interest of humanity (or expressive of a divine command) to treat animals respectfully. But, at the turn to the $19^{\text {th }}$ century, only very few thinkers considered animals themselves as bearers of rights. People had obligations against animals, not to them; that was the predominant view. ${ }^{15}$

Against that prevalent tendency, only very few authors demurred and made forays comparable in spirit and intention to Krause's efforts: Humphry Primatt fended for the considerate treatment of animals applying the golden rule to animals' capacity for suffering. ${ }^{16}$ Wilhelm Dietlar argued for the selfsame outcome oriented at an ethics of happiness for all life forms ${ }^{17}$ and Johann Georg Heinrich Feder based on a theory of ontological perfection, ${ }^{18}$ whereas Lauritz Smith did so from an inclusivist theology of creation. ${ }^{19}$ They all thus surpassed the characteristic style of their era, which limited human action towards animals, if at all, solely out of regard for human interest, e.g., out of an aversion towards cruelty and a concomitant concern that cruelty towards animals might eventually deteriorate also the standards of behavior between humans.

Nevertheless, it was Krause who first managed to integrate questions of animal ethics systematically into a genuinely modern philosophy of freedom which, premised as it was on a transcendental phenomenology, did not come with overly heavy metaphysical baggage. ${ }^{20}$ Whoever these days reaches back to Jeremy Bentham (cue: "capacity for suffering") and Arthur Schopenhauer ("animals are not things") in search of progenitors of reflections on animals' rights, ${ }^{21}$ should, therefore, study Krause's position.

\section{Animal Rights}

Krause held that humans were not the only beings on earth whose freedom-based rights have to be respected. Animals - Krause argued - might also deserve legal protection insofar and inasmuch as their respective freedom warrants ascribing person-

\footnotetext{
${ }^{15}$ For an overview see Garrett, et al., Animal Rights and Soul in the Eighteenth Century, 2000.

${ }^{16}$ Primatt, A Dissertation on the Duty of Mercy and Sin of Cruelty to Brute Animals, 1776.

${ }^{17}$ Dietlar, Gerechtigkeit gegen Tiere, 1787.

${ }^{18}$ Feder, Über die Rechte der Menschen in Ansehung der unvernünftigen Tiere, Neues hannoverisches Magazin 2 (1792), 945-960.

${ }^{19}$ Smith, Über die Natur und Bestimmung der Tiere wie auch von den Pflichten der Menschen gegen die Tiere, 1790.

${ }^{20}$ Bregenzer, Thier-Ethik: Darstellung der sittlichen und rechtlichen Beziehungen zwischen Mensch und Thier, 1894, 208. For a defense of the metaphysics within Krause's system see Göcke, The panentheism of Karl Christian Friedrich Krause (1781-1832): From transcendental philosophy to metaphysics, 2018.

${ }^{21}$ See, for instance, Regan, Animal Rights and Human Objections, 1989.
} 
hood to them. That is to say, Krause curbed the predominant speciesism of his age by means of a personalism that comprises but is not limited to the human species; a move in deliberate contrast to the anthropocentric take on nature predominant in his time and era (ERB 36). Krause's argument was, however, also not biocentric. Natural entities do not make their axiological status explicit. Nor is it always patent. One cannot grasp and do justice to animals' intrinsic value at first sight, so to speak.

Krause instead argued for an anthropo-relational approach: We must convey to the human consciousness, according to its own categories, all those natural boundaries it is to recognize and respect. While humanity, in order to situate itself within nature as adequately as possible, should strive to understand all of nature according to its own laws and strivings, situated as humanity is within nature, an external perspective or a God'seye view cannot be attained. Nature must therefore be reflected upon in a twofold way: Both from the human perspective, and, at the same time, with a critical awareness of the limits of this very perspective. We are, that is to say, to recognize each living being as something not designed for humanity but living according to its own freedoms (ERB 45), while also keeping in mind that, as far as we know, human beings are the only creatures on earth aiming to evaluate accurately said intrinsic value of other lifeforms (ERB 36).

That the intrinsic value of nature, which it is meant to have independent of our consciousness, cannot be gauged other than by our consciousness, hinders any direct derivation of norms from facts. For this reason, biocentric theories fail to establish immediate moral validity, as biological realities can factually constrain or compel but never counterfactually obligate us. Mere diagnoses, say of animal suffering, are insufficient in and of themselves; what humanity requires furthermore are valuations. Krause thereby avoids what later on George Edward Moore (1873-1958) called the naturalistic fallacy. ${ }^{22}$

Likewise, we must also not commit an obverse normative fallacy ${ }^{23}$ of introjecting our moral purposes teleologically into nature (VR 104). Krause opposes the tendency, often on display within Antiquity and throughout the Middle Ages up until eighteenth-century scholasticism, that metaphysically inscribed the respectively favored moral good as a supposedly inherent striving or destination into human or animal life, i.e., as moral pursuits that they would allegedly tend to 'by nature'. In short, ethical norms cannot be generated sidestepping the self-critical human consciousness and its freedom.

Krause, who instead derives his entire ethics from a transcendental phenomenology of human freedom, probes whether the categories for the moral evaluation of animal life can be gleaned from that perspective too. As a consequence, he intends to view nature not merely as a means and material for human freedom but also according to its own laws and "in its inner freedom and absoluteness" (Nph 82). The ontological degrees of freedom realized within given lifeforms are to be taken as pointers to their axiological status. - What does this spell out for the conceptualization of animal rights?

Since in the right to freedom lies the philosophical foundation of human rights, something akin holds for animals. Subjective rights are for Krause not limited to, but merely exemplified by, homo sapiens. Human rights thus rank as a subcategory of a more general theory of personal rights. Krause believes, "everyone will agree that rights instantly

\footnotetext{
${ }^{22}$ See Moore, Principia Ethica, 2005, § 12 and, for more detail, see Frankena, The Naturalistic Fallacy, Mind 48 (1939), 464-477.

${ }^{23}$ See Putnam, Ethics without Ontology, 2004, 75.
} 
must be expanded and extended to each lifeform with whom we cohabitate which we recognize as a self-centered being capable to relate to itself in cognitive, emotional, and volitional acts" (NR 14). Beyond what plants are capable of, i.e., basic self-determination (NR 13), a necessary feature for the attribution of personhood is a certain form of self-relation (ibid.), which - Krause declares - animals display. Rebuking Fichte's deduction that "animals cannot have feelings" (GA IV/1, 394; GA II/5, 423; see also FW XI, 363), Krause defends the internal emotional as well as mental life of animals.

While, certainly, we cannot enter directly into the mental horizon of animals (NR 18), we are allowed to infer, however, that what is true of our own body as a self-recursive physical entity (NR 250; VR 447; G II 146) should also hold for animals, i.e., that just as our body has germane faculties for self-awareness (e.g., proprioception) and selfdetermination (e.g., self-direction in space) which function in part independent of our higher cognitive capacities, likewise animals display incorporated forms of physical independence - that is, freedoms - which they appear to employ functionally for, amongst other things, self-preservation. All animals are, on this basic level, self-recursive beings and thus, for Krause, persons.

Surely, this concept of personhood does not meet the standards of Kantian moral philosophy where only those subjects capable of directing themselves via the moral law are considered persons. ${ }^{24}$ Yet, Krause prefers to lower the bar for the ascription of personhood and rather transform that Kantian distinction into one that differentiates higher from lower forms of personal life, according to the degree to which they can, or cannot, submit their respective freedoms to the moral law. The salient difference between animals and human beings is, in Krause's view, not one of having feelings, or being able to suffer, which either display; it is rather one of the specific degrees of freedom realized respectively. The human ability to recognize self-transcending rules and norms to which it is knowingly and willingly bound is not mirrored by animals, since "they determine themselves only according to finite sensory impulses and not according to eternally infinite concepts [...]" (VR 172). Within "the sphere of our experience" we thus rightfully see the human being as the only form of life (LL 115) to which belongs freedom in the all-embracing sense and, consequently, also a particular responsibility as well as a certain ethical primacy (AR 183).

Importantly, this differentiation of the human being from animals is not grounded upon actual mental accomplishments. In contrast, Krause thinks, that often, in terms of what we can assess empirically, there is not such a huge difference between intelligent animals and human beings who willingly or not live reduced to the realm of sensuality. What counts for the difference between the species is rather the potential form of reflexive self-determination: An ethical freedom to which only human beings (can) evolve within the course of their lives. Humans and animals are consequently not only gradually different from one another but also categorically. They, as a species, are divided by the difference which sets apart technical ratiocination (which is environmentally conditioned) from moral reasoning (which is unconditionally free) (NR 136). And this says Krause - constitutes a difference "in their entire essence" (LL 338). Unlike animals, mentally and/or physically limited human beings belong to a species of reflec-

\footnotetext{
${ }^{24}$ Renzikowski, „Der Geist ist willig, doch das Fleisch ist schwach“. Zum Begriff der Person bei Kant, in: Godinho/Kindhäuser/Verrel (Hrsg.), Dasein und Gerechtigkeit. Ser-aí e Justiça, Festgabe für Faria Costa, 2020, 155-171.
} 
tively autonomous beings; their disability may inhibit the articulation of their human nature, but this does not amount to a privation of said nature (LL 172).

Yet for Krause animals hold the rank of a person nonetheless, "because we assume that they know themselves in certain ways, sense themselves, and strive to maintain and perfect their selfhood according to sensory ends" (VR 172). A glance at our own pets teaches us, for example:

\footnotetext{
"that these beings show all those idiosyncrasies which express the lowest level of the spiritual personality; they feel themselves, feel pleasure and pain, they have representations and fantasy, as is well known they determine themselves according to social concepts, since within various individuals of the same species they nevertheless recognize the same species, e.g., just as every man distinguishes himself as man, so every animal accordingly discerns its own species. They are therefore intellectual beings [geistige Wesen] [...]" (VR 246).
}

While the majority of the thinkers of his era viewed animals merely as instinctively driven automata and thus posited them anthropocentrically as mere things, conveniently at hand for human purposes, Krause expressly recognizes their inherent capacity for self-determination and categorizes them as subjects of germane rights.

Right exists without regard to the person. No person has a privilege (no one anticipates the right of another), but every person has his or her right. This is just as true ... of the simplest (qui capere valet, capiat!) animals (NR 114).

To repeat, Krause does not view the freedom or personhood of animals on the same level with human life. Fully developed human beings are capable of reflexively orientating their basic faculties, i.e., they are capable of feeling their feelings, willing their willing, thinking their thinking, but also, feeling their thinking, willing their feeling, and reasoning their willing. Through these reflexive faculties, human beings are able autonomously to criticize and direct themselves not only according to instrumental rules of prudence but also according to the moral laws of reason (LL $115 \mathrm{ff}$.). Unlike human beings, animals are, as far as we know, incapable of such self-reflective freedom and the genuinely ethical finality this enables (NR $149 \mathrm{f}$.); therefore, they are deprived of precisely those rights which shape this third level of freedom.

As soon as one considers the animal as a self-inward being possessing self-consciousness and self-feeling, one demands that man should also be just towards animals. But no one will talk about an animal justice which animals themselves practice. That is because one does not consider the animal capable of grasping the idea of justice in order to make justice its end. Thus, one says: Man should be the guardian of all animals and man considers the entire animal kingdom as in need of legal representation [unmündig] and rightly so (VR 205).

It is not because animals cannot themselves demand their rights - children, minors, and the mentally ill are also often unable to do so (NR $149 \mathrm{f}$.) - but because they ontologically exist on a lower level of freedom that they have a different axiological ranking. Animals and humans thus possess different rights. Yet their rights are not any weaker. They belong directly to animals with the same binding force as human rights belong to human beings. Just as much as human rights, animal rights are unconditional. Animals have to work for their specific rights just as little as human beings do; no reciprocity commitments are called for. Just as with human beings whose autonomy is limited (such as children, disabled, and senile persons) a legal guardianship is to be applied to animals, so that "the contingent conditions of the completion of their purely animalistic life are guaranteed" (VR 246). 
On Krause's view, animals possess a right to a self-determined life which deserves protection insofar as they (unlike predators at times) do not violate higher level, i.e., human rights (NR $136 \mathrm{f}$.). ${ }^{25}$ That which humans, as the representatives of the highest degree of freedom and autonomy on earth, may enforce upon others of the same standing, e.g., the elimination of unlawful violence, may also be enforced upon every being belonging to a lower level of freedom. If we are allowed to limit the use of our shared environs - by enforceable laws - for the protection of everyone's freedom, then we are also allowed to limit that of animals insofar as their rightful interests are respected. Since, for instance, humans may recycle their own organic waste products (hair, nails, etc.), they are entitled to do the same with animal offal. Krause also thinks that it may be possible to use animal labor "for reasonable purposes" and thereby curtail animals" natural freedom of movement (NR 137). Such a use - he contends - does not automatically impinge upon the respective animal's right to freedom if it serves acceptable ends and does not distress the animal (VR 246), as we are wont to make similar use of human labor.

More far-reaching rights appear, however, problematic. May humans, who must not kill one another for the purpose of nourishment, eat animals? Only insofar - states Krause - as "without such killing humanity on earth could not exist, unless some other kind of nourishment were found" (LL $300 \mathrm{n}$.). That is, his theory hardly provides a justification for the industrial exploitation of animals for gourmet purposes. After all, already at his time, Krause believed that the justifying condition, i.e., that otherwise human life could not be guaranteed, only rarely applied. Most people - he holds already have access to vegetarian food of adequate quantity and quality. And to destroy animal life without need cannot, according to Krause's theory, be justified at all, since one thus negates the natural freedom of animals without justificatory reason.

Although Krause claims that animals "have a right to bodily well-being, to absence of pain, and to requisite nutrition" (VR 246), he does not advocate that it is incumbent on humanity to assure a most comfortable existence for every lifeform on earth. As a general rule, animals are quite capable of taking care of their own well-being themselves, of obtaining their own food and avoiding pain, etc. - They thus realize their natural rights as a result of their own capabilities and freedom. But human interference with the animal biospheres requires due diligence (LL 117). If one takes animals out of their original habitat, or if one limits it, and so impairs their capacity for self-care, then a duty to species-appropriate treatment and nutrition follows hot on the heels (NR 136n.). This conclusion Krause optimistically believes would concur with a pervasive "feeling favoring justice for animals," which "cannot be eradicated" from the human mind (NR 137).

In later writings, however, Krause modified his previous teachings and distinguished between higher and lower developed animal species, ranking only the former as legal persons (LL 116). He did not, though, go into detail as to what animals were to fall under which rubric. However, the criteria he had previously employed to mark out the (lower) status of personhood of animals (individual conception of self, capacity of conscious

\footnotetext{
${ }^{25}$ The right of animals to constitute themselves was later also recognized by Salt, Animals' Rights Considered in Relation to Social Progress, 1892. Like Krause, Salt also recognizes in the moral law the legitimate limit of animal behavior (to be enforced by humanity) so that a guardianship of humans over animals has to be realized (ibid., 46). See Flury, Der moralische Status der Tiere: Henry Salt, Peter Singer und Tom Regan, 1999, 96 ff.
} 
self-direction) could well be used to establish this very distinction, based on empirical insights about the capabilities of given animal species. ${ }^{26}$

\section{Ecological Sustainability}

As we saw, Krause aims to guarantee an optimum of compossible freedoms to animals and humans through legal representation and protection. For both humans and animals, this implies a facilitation of the requisite space and opportunities for free development, based on an ethics that recommends moral consideration in close proportion to the different levels of freedom characteristic of a given entity. But what kind of ethics should we apply when the object of free activity is no longer a self-conscious animal but rather an unconscious plant, or even a nonliving object? Since life's ontological grades of freedom are the main criterion, how is humanity to deal with plants and all forms of inorganic matter?

Plants represent a form of life, which, internally as well as externally, certainly exhibits functional self-organization in space and time, but not conscious awareness and self-direction. But the idea of freedom requires conscious life, and thus only comes into its own when an entity knows about itself and its environment. Plants - and inorganic matter a fortiori - are therefore justly considered merely as objects, not subjects of a freedom-oriented ethics. Biocentric theories propounding the ethical equality of human life with plant life cannot, consequently, find support in Krause.

So, what boundaries are then still to be drawn, or can human freedom, exempting human and animal life, enjoy unhindered choice and exploit the world as it pleases? Which liberties may human freedom take with unfree entities? To unlock the answer to this question, we need to dwell on the fact that Krause looked for freedom less in independence from, but rather in interdependency with, its environments. On his view, human beings develop themselves and their freedom not so much in abstraction from their biological and social contexts as in and through them. From this relational understanding of personal life, there results a sustainability-orientated concept of freedom. Clearly, humanity should maintain the natural preconditions of its own life if - in using its freedoms - humankind does not want to negate its biological preconditions (VR 58). As our freedom always depends on a natural context, everyone - Krause felt - should demand the "protection, maintenance and support of nature" (NR 135), since, clearly, water, sun, air, and soil can be so despoiled as to become unsuitable for human use.

A corollary of this tenet is that nothing in nature can ever be absolutely worthless (AR 182). There always remains the possibility of serving somehow, someone, at some time, as a means towards freedom (NR 139). Sustainability-oriented policies, that is to say, protect future freedom. Against that prospective value, anyone disturbing or destroying the environment must justify their actions; they have to make it plausible that they thus create more, or better freedom than they are about to annihilate. ${ }^{27}$ Unlike most liberal thinkers from his time up to today, Krause therefore does not first allow the use of nature abstractly, only to then, subsequently, limit it concretely as required. Rather, he prohib-

\footnotetext{
${ }^{26}$ Flury, Der moralische Status der Tiere, 1999, 42 ff., comes to similar criteria catalogues (with changing accents).

${ }^{27}$ Fernández, La filosofía del derecho de K. Ch. F. Krause: Con un apéndice sobre su proyecto Europeísta, 2000, 227-234.
} 
its from the outset every useless and purposeless destruction of nature. In that vein, Krause rejects Fichte's view that rights are confined to inter-human relations but could not concern "air" or "light", with the terse rejoinder: "Not so, as the air I need to breathe can be polluted and made unhealthy, or that light that I require can be blocked by someone" (K 36).

Similarly, Krause objects to any excessive exploitation of nature: "Things are to be consumed, that is destroyed through their use, (a) only under the condition that they can promote higher living-being (a higher amount of the good or a higher good); and (b) only if the damage which they inflict on living beings could otherwise not be prevented" (NR 144n.). Krause thus anticipates the precautionary principle and shifts the burden of proof from the defendants of nature upon those who wish to instrumentalize it.

From these qualitative directives results the quantitative radius of the legitimate use of objects. Use without consumption or wear and tear can be granted without limit (NR 176). Regarding objects with multiple uses, an examination is due, which of these should be given priority, e.g., it might be advisable to use wood rather as "timber than firewood" (NR 176). Any appropriation of nature must first be regulated by public, i.e., political, self-determination, with a view to the notion of an originally communal possession of the earth by all present and future persons functioning as its moral corrective.

\footnotetext{
"Prior to public distribution, no individual possesses a legitimate right to some kind of useful thing except his own body, and only the public allocation according to just division is the form in order to obtain the rightful possession of something useful. Whoever wishes to take possession of something must first be entitled by everyone for this appropriation, just as is the case with whoever intends to work on something; [...] No individual can be placed by another individual in the rightful possession of some kind of useful thing or be driven out of such possession" (G II 191).
}

On these premises, Krause erects an impressively cosmopolitan doctrine of the rights to acquisition, ownership, and usufruct, which cannot be done justice to within the scope of this paper. ${ }^{28}$ But the decisive idea behind these deliberations should once again be pointed out: Krause qualifies the idea of freedom by a theory of relational personhood based on the interdependence of persons with their social and natural environments. Accordingly, Krause relates the fundamental right to a free life to the specific social and environmental preconditions of personal autonomy. Because of the central role of social spaces of interaction for the development of personal freedom, his theory of freedom thus ultimately leads to a sketch of a public order in the service of universal freedom. That order is to be structured by emancipatory forms of interaction so that the liberties of everyone are promoted by the freedoms of all.

This holds true especially with regard to the appropriation and ownership of natural objects. To be protected under the aegis of a freedom-based system of human rights, the privatization of property must never turn into an end in itself but always has to remain a means only - a legal attribution to be modulated and curtailed in the name of the overarching cause of universal freedom it serves. While, generally, the state may operate under the assumption that private possessions are put to appropriate use, this assessment, however, may have to be reversed (preventatively) in the case of goods of extreme societal relevance. Krause is thinking of forestry and agriculture, for instance,

\footnotetext{
${ }^{28}$ For more details, see: Dierksmeier: Qualitative Freedom - Autonomy in Cosmopolitan Responsibility, New York/Heidelberg: Springer 2019, chapter 2.3.3.
} 
whose undertakings should remain under public supervision because of their vital importance for the ecological sustainability of human life - according to the one and selfsame notion that guides his approach throughout: the idea of universal freedom which not only legitimates private liberty and property, but also limits it so that the freedom of all can be assured.

\section{Final Remarks}

If all of this is true and if Krause philosophized with such astonishing foresight some readers might ask - why have we never heard of him before? Why do we not find statues of him, streets named after him, and busts portraying him in our public squares? Why does his name not appear in most histories of philosophy? Indeed, anyone who searches for Krause on the internet or within appropriate lexica within the German and English-speaking academic world often finds his work, if portrayed at all, much less favorably presented than here. Krause is condemned for abstruse language (cue: long compound nouns with numerous pre- and suffixes), fantastical ideas (cue: brotherhood of humanity, universal destination of all goods, etc.), and uncommon metaphysical preferences (cue: his panentheism), and thus the impression may well arise that he was justly forgotten.

Elsewhere I have endeavored to rebut these objections in detail. ${ }^{29}$ Here I must confine myself to but a few cursory remarks. It is true that Krause worked out his own technical terminology, which does indeed make the appropriation of some of his later works difficult. Although this was not always the case - some of his writings and posthumously published lectures are very clearly, even elegantly written - Krause's at times excessive recourse to his own philosophical terminology has certainly hindered the reception of his thought in his homeland.

The external occasion for this new argot was the religiously charged situation at the University of Jena. First, his teacher Fichte was forced to leave the university because of the so-called atheism controversy and, subsequently, in the wake of the so-called pantheism controversy, Schelling decided to leave as well. ${ }^{30}$ Krause, who had developed his own philosophy through critical engagement with theirs, did not wish to get into the crosshairs of religious zealots. Moreover, Krause wished to escape the ambiguities of quotidian philosophical concepts (like "God", "the Absolute", etc.) through a regularly constructed derivation of the required technical terms so as to bequeath to philosophy a logically unambiguous terminology. Other thinkers with similar aspirations, like Leibniz (with his 'mathesis universalis') attained more recognition for such efforts, however, than did Krause.

It seems to me that the actual reason for Krause's poor reception in Germany was much rather his unfortunate academic career. In his time, only a few philosophers outside the university system could raise their work into public awareness. Krause, though, never managed to get hold of a regular professorship. This had to do, for one thing, with

\footnotetext{
${ }^{29}$ See Dierksmeier, Der absolute Grund des Rechts, 2003. For a thoroughgoing rebuttal of these accusations see Göcke, The panentheism of Karl Christian Friedrich Krause.

${ }^{30}$ For more information see Kodalle/Ohst, Fichtes Entlassung: Der Atheismusstreit vor 200 Jahren, 1999.
} 
envious chicaneries from political and academic opponents ${ }^{31}$ and, for another, with Krause himself. First, it seems obvious that Krause, who was avidly fighting for the elimination of any kind of religious, sexual, and racial discrimination, thus put himself at odds with the zeitgeist, exemplified by the renowned German philosophers of his day and their often staunch nationalistic and sexist chauvinism. Nor did his stance in favor of the rights and personhood of animals make him palatable to the mainstream. Second, though, one must not overlook that Krause certainly did not promote either himself or his work. Tactical maneuvering was alien to his nature. Trusting that his philosophy spoke for itself, he (all too?) peacefully acquiesced to inferior employment contracts and chose to apply his energies to the development and perfection of his system at the expense of its marketing. He simply had no desire to be a public intellectual. Therefore, the true responsibility for the lack of prominence of his philosophy lies, in my estimate, more within his personality than in his philosophy, whose rediscovery is very much to be hoped for. Facing enormous environmental challenges and searching for a healthy mean between an irresponsible libertinism on the one hand, and the equally unappealing alternative of an eco-dictatorship on the other, the global community today has much to discover in Karl Christian Friedrich Krause's alternative.

Claus Dierksmeier,

Eberhard-Karls-Universität Tübingen,

E-Mail: claus.dierksmeier@uni-tuebingen.de

\footnotetext{
${ }^{31}$ For a more detailed discussion see Ureña, K. C. F. Krause: Philosoph, Freimaurer, Weltbürger, 1991.
} 